\title{
Land Policy Issues in Nepalese Context
}

\author{
Gandhi Subedi \\ Under Secretary, Land Reform Office, Kathmandu \\ Raja Ram Chhatkuli \\ Director General, Survey Department
}

\section{Key Words:}

Land Policy, Land policy instruments

\begin{abstract}
The land issues comprise all social, economical and legal measures that determine the access to land and allocation of land related benefits. Land administration plays important role in obtaining national political objectives by operating land policy instruments properly. This paper aims to discuss various land policy issues in Nepal. The literature regarding land policy and land administration, concerning laws and reports are reviewed. The concept and definition of land policy and land administration and their relationship is provided first; and then the land policy issues and major challenges are discussed, some measures to overcome such challenges are also presented; and conclusion is drawn from the whole study. Lack of national land policy and land use policy, no guarantee of registered deed, lack of fair compensation in case of expropriation, lack of clear governement policy to regulate land market, improper land valuation system, traditional, complex and cumbersome procedure, lack of coordination between land administration organizations, poor management of land records, manual recording system, lack of one stop shopping, difficult to retrieve land information, lack of skilled manpower, misuse of public land, lack of national policy to provide land to the landless and poor people and protection of rights of the indigeneous people are the major problems identified from the study. Formulation of national land policy and land use policy addressing all land issues, improvement in registration system, simplification of procedures, integration of land administration organizations, digitization of land records, establishment of National Spatial Data Infrastructure, providing online services and hiring trained manpower/providing training to existing manpower are some of the measures for improvement in the existing land administration system of Nepal.
\end{abstract}

\section{Introduction}

Land administration plays important role in obtaining national political objectives by implementing land policy instruments properly. In Nepal, the system of land administration was developed for the purpose of collecting land revenue. Presently, its role and functions are increased. This paper aims to evaluate the land administration system of Nepal from different perspectives and explore its challenges.

The concept of land policy, land administration and land governance is provided in Section 2. In Section 3 , the status of land policy issues and major problems are discussed. Finally, conclusion is drawn in Section 4.

\section{Concept \& Definition}

The concept of land policy, land administration and land governance and the relationship between land policy and land administration is provided in the following sections:

\subsection{Land Policy, Land Policy Instruments \& Land Administration}

Land policy concerns with the allocation of land and land related benefits. United Nations Economic Commission for Europe (1996:58) has stated that "the land policy consists of a whole complex of socio-economic and legal prescriptions that dictate how the land and the benefits from the land are to be allocated". This definition has considered that the land issue comprises social, economical and legal measures to allocate land and land related benefits. Deininger (2003:178) has defined land policy in the same way. According to him, land policy is the rules governing access to and the distribution of the benefits from one of the economy's main assets.

The European Union Land Policy Guidelines (European Union, 2004) has described that the land 
policy aims to achieve certain objectives relating to the security and distribution of land rights, land use and land management, and access to land, including the forms of tenure under which it is held; defines the principles and rules governing property rights over land and the natural resources it bears as well as the legal methods of access and use, and validation and transfer of these rights; details the conditions under which land use and development can take place, its administration, i.e. how the rules and procedures are defined and put into practice, the means by which these rights are ratified and administered, and how information about land holdings is managed; and specifies the structures in charge of implementing legislation, land management and arbitration of conflicts.

Thus, the land issues comprise all social, economical and legal measures that determine the access to land and allocation of land related benefits.

Land administration is defined as the process of determining, recording and disseminating information about the ownership, value and use of land, when implementing land management policies (United Nations Economic Commission for Europe, 1996:13-14). This definition comprises the relationship between the tools and land policy. Land settlement, land survey, land registration, land valuation and assessment, land use control and management are the activities involved in the land administration (United Nations Economic Commission for Europe, 1996:58).

van der Molen (2008) has mentioned that political objectives such as economic growth, poverty reduction, sustainable housing and agriculture, social equity and fairness, protection of vulnerable groups in society, require a policy of the government how to deal with the allocation of access to land and land related benefits. It requires intervention measures of a more technical nature which concern the application of property right regimes, the extent to which a government wants to secure those rights, access to credit markets, the regulations of the
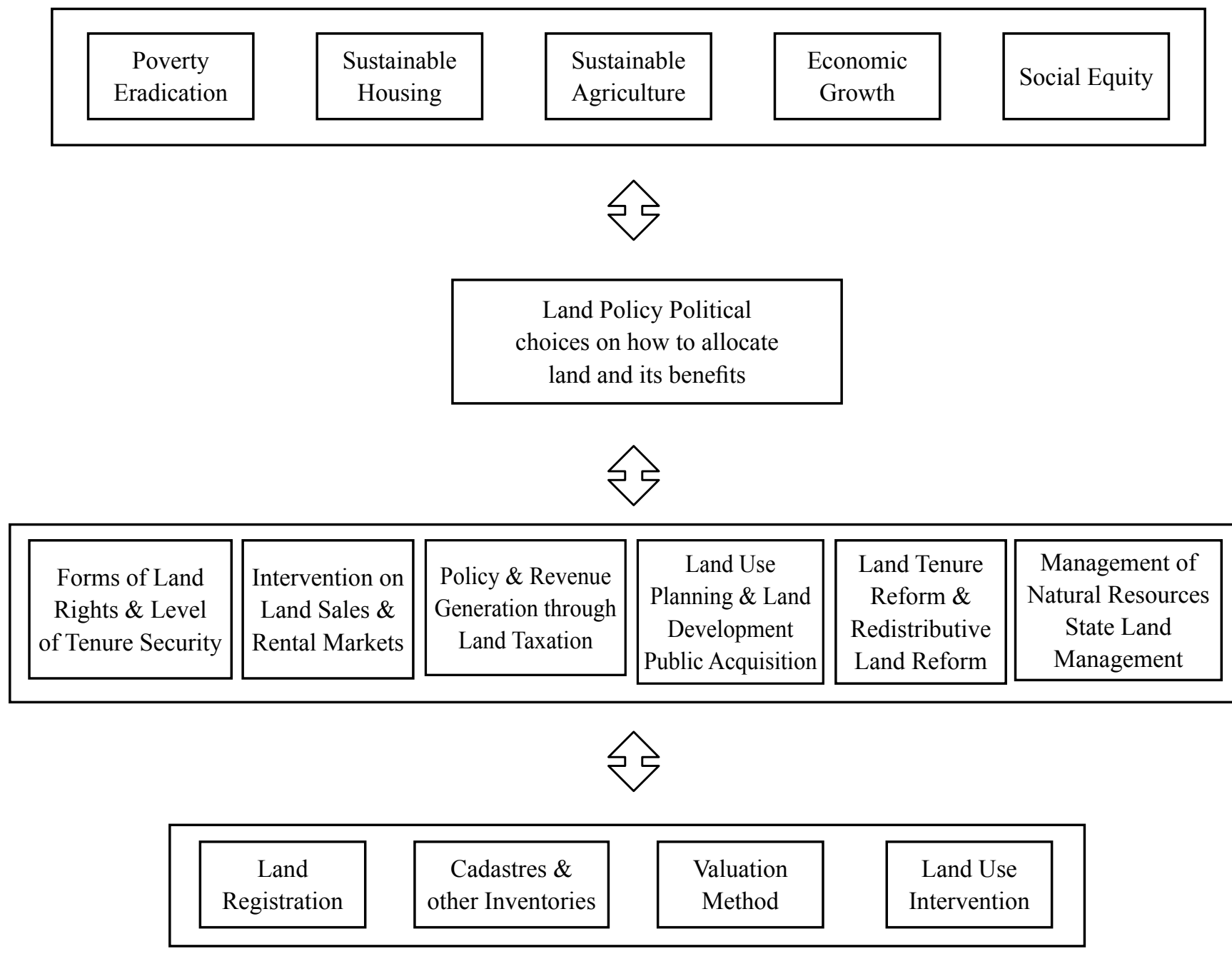

Figure 1:Relationship among national objectives land policy and land administration

(van der Molen, H. Silayo et al. 2008) 
land sales and rental markets, the measures to enhance sound land use planning, land reform, land taxation and management of natural resources which are called land policy instruments. Land administration is a tool to operate land policy instruments. The relationship between land policy and land administration is shown in Fig. 1.

\section{Nepalese Context} below:

The status of land policy instruments is discussed

\subsection{Land Tenure Arrangements}

There is statutory land tenure system in Nepal. The privately owned land is called Raikar which is of freehold nature. Tuladhar (2004) has mentioned that "the present Raikar tenure system allows distinct relationships between the landholders and the land through ownership providing a bundle of real rights, which can be held, used, inherited and enjoyed by landholders on the condition that they keep paying the tax fixed annually by the state". There is another category of land called Guthi or trust land which is an endownment made by any philanthropist for religious or philanthropic purposes. The State land is also categoriseed as government land and public land. There is provision of leasehold as well. All other types of land tenure systems such as Birta, Ukhada, Kipat, Jagir, Jhora, Kharka, etc. are abolished in the past.

The landowner can enjoy all kinds of rights over own land however, the governement can expropriate any kind of land if it is required for the public purposes. According to the Article 19 of the Interim Constitution of Nepal, the State requisite, acquire or create any encumbrance on the property of any person (this clause shall not be applicable on prpoerty acquired by illegal means) except in the public interest and compensation shall be provided if it is requisited, acquired or encumbered by the State in implementing scientific land reform program or public interest in accordance with law. So, the State cannot expropriate private land without compensation. The amount of compensation is determined by a committee formed under the Chairmanship of Chief District Officer. Also, there is deed registration system in Nepal. The deeds are considered as evidences and firstly registered deeds get priority over late registered or non-registered deeds. However, any damage caused by the mistraque duting land transaction is not covered by the State. Because of the minimum valuation system, normally the land value determined by the Minimum Valuation Determining Committee formed under the Chairmanship of Chief District Officer in each area is mentioned in the deed of transaction which is generally less than the market price. In case of dispute over land transaction, only the amount mentioned in the deed is returned to the buyer if the deed is dismissed by the Court. The amount of compensation of acquired land is also determined based on the minimum valuation. So, the amount of compensation is generally lower than the market price.

\subsection{Land Market}

Land is an immovable asset so that it can not be handed over from one person to another during transaction. The right of land is transferred by means of registration of deeds or title. So, the land is also considered as tradable good in the land market.

Land transactions can play an important role by (a) providing land access to those who are productive, but who own no or little land; (b) allowing the exchange of land as the off-farm economy develops; and (c) facilitating the use of land as collateral in credit markets (Deininger, 2003: 79). However, this situation is not always true. Factor such as difficulties to prove evidence of ownership, unequall access to infomration, high transaction costs, bureaucreatic procedures, subsidies and fiscal measures, planning and public acquisition, etc. causes distortions in the land market (van der Molen, 2008). The land market imperfections most likely do neither direct land to its most productive use, nor provide equall access to land ownership or access to land related benefits, from which the poor have to suffer (van der Molen et. al., 2009).

Land speculation also affects in the wellfunctioning of land market. It promotes development of unplanned settlements, encourages urban sprawl, increases the cost of delivering services, creates an artificial shortage of development land and interferes with the government's desire for fair distribution of land (van der Molen et. al., 2008). Holding of large track of land also influenced in the land market.

In Nepal, there is lack of governement policy to regulate land market. Most of the transactions in the rural take place through the personal contact usually mediated by the local elders or the person known by both of the parties. While in urban and peri-urban areas, the transaction is mediated by the real estate agents and land brokers. In such cases, the middle man can play important role in price determination and get benefit from it. There is no proper policy to regulate the real estate market. In recent years, the land price of the urban and peri-urban area is raising unexpectedly due to speculation, land holding and some social, economic and political reasons. 
The credit market is also not developed well. In recent years, the finaincial institutions had increased investment in real estate and housing sector. However, after the depression in the world economy, they have cut down their financing in this sector. The process of finaincing is also very comples.

Contribution of real estate sector in the national economy has been increaased in recent years. According to the Economic Survey, the contribution of real estate, rent and business sector to the GDP has reached to $10.16 \%$ in the FY 2063/64 which was only $8.29 \%$ in the FY 2057/58.

\subsection{Land Value, Valuation \& Taxation}

Land has certain value. The value of land should be recognized for different purposes such as land transaction, land/property taxation, rent, compensation of expropriated land, etc. So, proper land valuation and taxation policy is required.

In Nepal, the value of buildings is determined by the local bodies and that of land is determined by different authorities for different purposes. For instance, the minimum valuation of land determined by the Land Revenue Offces is used to mention in the deed of transfer; the financial institutions determine land value to fix the loan amount, District Administration Office fix the land value while determining compensation of expropriated land; and the local bodies also determine land value for taxation, property evaluation and other purposes. For the registration purpose, the valuation of building is determined by the local bodies.

There is no similarity between the value determined by different agencies although the land is same. The value determined by the Land Revenue Offices is upto 3 or 4 times lower than the current price of land in many areas whereas in some areas, it is higher than the current price. The value determined by the financial institutions and District Administration Offices is also lower than the actul price. So, normally the landowners pay lower land tax and registration fee and get lower loan and compensation from their land.

The amount of land revenue collected in the Fiscal Year 2031/32 was Rs. 90.9 millions and only Rs. 91 million was collected in the FY 2050/51. The authority to collect land revenue is given to the local bodies since B.S. 2052 and its amount is not published in the national accounts since few years. Similarly, the amount of registration fee collected from the Land Revenue Offices reached to Rs. 6.23 billions in the FY 2065/66 from Rs. 36 millions in the FY 2031/32.

\subsection{Land Use Planning, Implementation \& Maintenance}

Certain governemnt interventions are required to use the available land as per the needs of the society. Planning regulations, public acquisition and expropriation and regulations for informal settlements and peri-urban areas are some of these interventions.

Land use planning (physical planning) is the process of allocating resources, particularly land, in order to achieve maximum efficiency while respecting the nature of environment and the welfare of the community (United Nations Economic Commission for Europe, 1996). Land use planning influences the private property rights. During the planning process, the effects are indirect, however, while implementing such planning, the public law measures will restrict the right to dispose by private owners and maintaining the given land use will prohibit the land owners to deviate from the regulations (van der Molen, 2008). Thus, the land use planning should be legitimate and requires institutional prerrequisites. The Land Administration Guidelines (United Nations Economic Commission for Europe, 1996) has described that there should have a formal relationship with the land administration system because of the impact that development proposals will have on the land and the associated land rights and the responsible administrative authority must adopt the administrative procedures that work closely with the cadastral system.

The government can impose restrictions on private property rights by means of land use planning. Sometimes, the government requires privately owned land for public purposes. In such cases, the government needs to acquire private land in accordance of law. There are four main types of public acquisition of land: try to buy the land right as a private buyer, imposing a pre-emptive rights, expropriation and land consolidation and consolidation. The expropriation is the ultimate government intervention. It should be strictly regulated by law and taken place only for the public purpose. Compensation should be provided in case of expropriation.

In Nepal, national land use policy is not formulated yet. So, there is lack of land use planning which has caused the haphazard and unplanned development of settlements and misuse of fertile land. It has also caused problem in balanced development. Also, there is lack of fair compensation in case of expropriation of privately own land for public purposes. 


\subsection{Land Reform}

Land Reform is a broad term and can have different meaning. Land redistribution, land tenure reform, land nationalization, agrarian collectivisation, land restitution, land consolidation and readjustment are the main types of land reform.

The measure of land reform is applied to reduce the unequal distribution of land, provide access to land to the poor and landless people and increease productive efficiency. Deininger (2003) has described that the unequal and often inefficient distribution of land in many developing countries was the outcomes of power relationship and dostortionary policies rather than market forces. Only the market forces cannot lead to land redistribution to the desirable extent to maximize efficiency and welfare outcomes which has justified for land reform. He has also stated that many historical and contemporary conflicts have their roots in struggles over land. These issues should be addressed by the land policy.

In Nepal, land reform program was started in B. S. 2021 by the then King Mahendra from the purpose of justifiable allocation of agricultural land and improvement in the living standard of tenant. Fixation of land ceiling for land owner and tenant, acquision of land beyond ceiling, fixation of rent, protection of right of tenant, etc. are the main features of this program. The Fifth Ammendment (2058) in the Land Reform Related Act, 2021 has provisioned for allocating $50 \%$ of land to the tenant.

The commissions Forest Sector Reform High Level Commission, Commission for Solving Landless Problems, etc. has also allocated land to the landless and poor people including informal settlers and migrants in different time periodds. However, such problems are not solved yet. Also, the dual ownership of land is not finished.

\subsection{Management of Natural Resources}

Management of natural resources is not possible without proper land management. So, this issue should also be addressed by the land policy. It includes recognition of existing land tenure (e.g., mining rights, water rights, hunting rights, etc.), management of public land, management of environment and pastoralist's land right.

In Nepal, there is no concrete policy regarding management of public land. Article 24 of the Land Revenue, 1978 has prohibited cultivating and registering public and government land under the name of any individual. The government had formed a High Level Commission regarding Investigation and Protection of Government and Public Land (Rawal Commission), however, its report is not fully implemented yet.

The government has also approved the ILO convention 169 regarding the right of indigenous people which also includes the land right of such people. However, different forms of land tenure rights are not legally recognized. There is not clear policy regarding protection of rights of the indigeneous people (including fishing right, huning righ, etc.)

\subsection{Problems}

Although the land registration and other land administration services are faster than some countries, Nepalese land administration is not free from problems which are listed below:

- Lack of national land policy and land use policy

- No guarantee of registered deed

- Lack of fair compensation in case of expropriation

- Lack of clear governement policy to regulate land market

- Improper land valuation system,

- Traditional, complex and cumbersome procedure

- Lack of coordination between land administration organizations

- Poor management of land records

- Manual recording system

- Lack of one stop shopping

- Difficult to retrieve land information

- Lack of skilled manpower

- Misuse of public land

- Lack of national policy to provide land to the landless and poosr people and protection of rights of the indigeneous people (including fishing right, huning right)

Measures to overcome from these problems are: formulation of national land policy and land use policy addressing all land issues, improvement in registration system, simplification of procedures, integration of land administration organizations, digitization of land records, establishment of National Spatial Data Infrastructure, providing online services and hiring trained manpower/ providing training to existing manpower. 


\section{Conclusion}

Land policy is one of the national policies which concerns with the allocation of land and land related benefits. Land tenure arrangements, land markets, land taxation, land use planning, implementation and maintenance, land reform and management of natural resources are the instruments of land policy and land administration is a tool to operate these instruments.

Deed registration system, fast services, separate land registry and cadastre, statutory land tenure system, no financial autonomy are some of the features of Nepalese land administration system. Lack of national land policy and land use policy, no guarantee of registered deed, lack of fair compensation in case of expropriation, lack of clear governement policy to regulate land market, improper land valuation system, traditional, complex and cumbersome procedure, lack of coordination between land administration organizations, poor management of land records, manual recording system, lack of one stop shopping, difficult to retrieve land information, lack of skilled manpower, misuse of public land, lack of national policy to provide land to the landless and poosr people and protection of rights of the indigeneous people (including fishing right, huning right) are its major problems.

To conclude, the land administration system of Nepal has both strengths and weaknesses. Formulation of national land policy and land use policy addressing all land issues, improvement in registration system, simplification of procedures, integration of land administration organizations, digitization of land records, establishment of National Spatial Data Infrastructure, providing online services and hiring trained manpower/providing training to existing manpower are some of the measures to solve these problems.

\section{References}

1. Deininger, K. (2003). Land Policies for Growth and Poverty Reduction. London, The World Bank \& Oxford University Press: 239.

2. European Union (2004). EU Land Policy Guidelines.

3. Tuladhar, A. M. (2004). Parcel-based GeoInformation System: Concepts and Guidelines. Enschede, ITC. PhD: 252.

4. United Nations Economic Commission for Europe (1996). Land Administration Guidelines. New York, Geneva, United Nations: 81.

5. van der Molen, P. (2008). Land Policy. Land Policy and Land Management. Enschede, The Netherlands, ITC.

6. van der Molen, P., E. H. Silayo, et al. (2008). A Comparative Study to Lna Policy in 9 Countries in Africa and Asia. Integrating Generations, FIG Working Week, 2008. Stockholm, Sweden, FIG. 